\title{
Duplicate growth hormone genes in sheep and goat
}

\section{Wallis, A Lioupis and O C Wallis}

\author{
Biochemistry Laboratory, School of Biological Sciences, University of Sussex, Brighton, \\ East Sussex BN1 9QG, UK
}

(Requests for offprints should be addressed to M Wallis)

\section{INTRODUCTION}

In most mammals a single gene codes for pituitary growth hormone $(\mathrm{GH})$ and is not associated with closely-related genes. An exception occurs in higher primates. In man a cluster of five genes on chromosome 17 codes for GH-like proteins; one of these (at the $5^{\prime}$ end of the cluster) codes for pituitary $\mathrm{GH}$, while the other four code for genes expressed in the placenta, including two genes for placental lactogen, one for a placental lactogen-like protein, and one for a GH variant (Chen et al. 1989). In rhesus monkey, studies on cDNA indicate that there are at least five genes that code for GH-like proteins, one expressed in the pituitary and four in the placenta, although these may not be exactly equivalent to the human GH-like genes (Golos et al. 1993). There is also evidence for multiple GH-like genes in a new world monkey (O C Wallis \& $\mathrm{M}$ Wallis, unpublished observations). These clusters of GH-like genes have presumably arisen as the consequence of duplications of the single GH gene found in most mammals (and other tetrapods), followed by divergent evolution. It is notable that evolution of $\mathrm{GH}$ in primates involved a burst of rapid change (contrasting with general conservation of GH structure seen in most mammals) which appears to have occurred before the gene duplications that gave rise to the gene cluster(s) (Wallis 1994, 1996).

Until recently it appeared that duplication of the $\mathrm{GH}$ gene in mammals was confined to primates. Placental lactogens are found in some other mammalian groups (ruminants, rodents) but appear to have arisen independently of those found in primates, by duplication of the prolactin gene (Schuler \& Kessler 1992, Wallis 1992). However, a number of reports have now appeared indicating that there are duplicate $\mathrm{GH}$ genes in at least some caprine ruminants (goats and sheep). These have interesting implications for the evolution of the $\mathrm{GH}$ gene in ruminants.

\section{DUPLICATION OF GH GENES IN CAPRINE RUMINANTS}

On the basis of studies on a restriction fragment length polymorphism (RFLP), Valinsky et al. (1990) concluded that there are two alleles at the $\mathrm{GH}$ gene locus in sheep and goats. In sheep, in one allele (Gh1), the GH gene is represented by a single copy (GH1 gene), while in the other (Gh2) the GH gene is duplicated $\left(G H 2-N\left(5^{\prime}\right)\right.$ and $G H 2-Z\left(3^{\prime}\right)$ genes). Restriction maps of the sheep Gh1 and Gh2 loci indicated that the GH1, GH2-N and GH2-Z genes are all very similar (Fig. 1). The sequences flanking the $5^{\prime}$ ends of the $G H 1$ and $G H 2-N$ genes are similar, but differ from that flanking the $\mathrm{GH} 2-\mathrm{Z}$ gene. Individual animals were homozygous for Gh1 (i.e. possessed $2 \mathrm{GH}$-like genes) or Gh2 (4 GH-like genes) or heterozygous, with one copy of Gh1 and one of Gh2 (3 GH-like genes). The frequency of the Gh2 allele was greater than that of the Gh1 allele. Subsequently, Gootwine et al. (1993) showed that the $G H 2-Z$ gene contains a PvuII polymorphism in the second intron and Gootwine et al. (1996) concluded that, in an animal homozygous for the Gh2 allele, only the $G H 2-N$ gene was expressed in the sheep pituitary. Sequence differences between the sheep GH2-N and GH2-Z genes have now been demonstrated by Ofir \& Gootwine (1997) (see below). Lacroix et al. (1996) have shown that two forms of $\mathrm{GH}$ are expressed at low level in the sheep placenta, one of which is probably identical to pituitary GH while the other differs from it in sequence and is probably the product of the $\mathrm{GH} 2-\mathrm{Z}$ gene. 

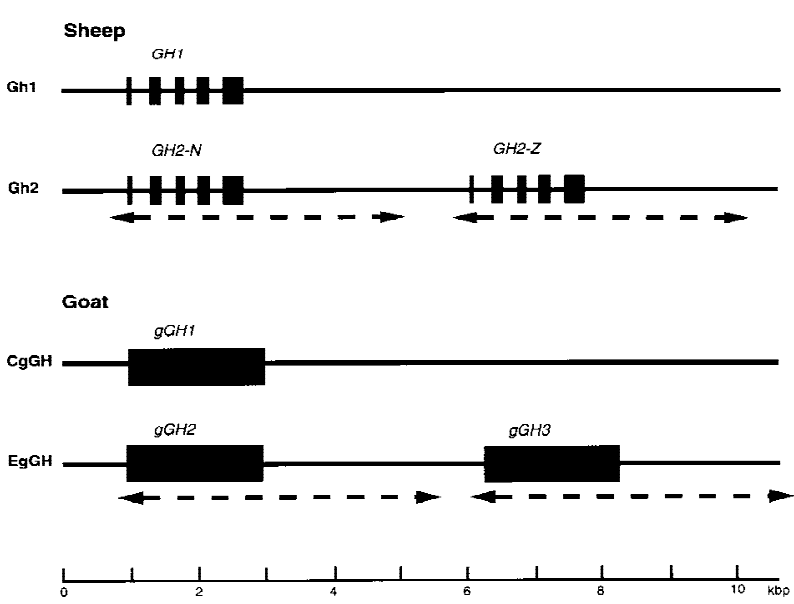

FIGURE 1. Organisation of the growth hormone-related genes in sheep and goat. Gh1 and Gh2 are the two alleles in sheep (based on Valinsky et al. 1990), $\mathrm{CgGH}$ and $\mathrm{EgGH}$ the two in goat (based on Yamano et al. 1991). Intron/exon structure is indicated for the sheep genes; it is likely to be very similar for the goat genes, but has not yet been formally demonstrated in each case. The dashed arrows indicate the apparent duplicate regions, based on sequence and restriction mapping (sheep) and restriction mapping and distribution of repetitive sequences (goat).

Yamano et al. (1991) investigated GH genes in a goat genomic library and found two types of fragment, one containing a single $\mathrm{GH}$ gene ( $g G H 1)$ and the other containing two genes arranged in tandem ( $g G H 2$ and $g G H 3)$. Again this appears to be due to allelic polymorphism, with the allele containing duplicate GH genes predominating. The tandem arrangement of the $g G H 2$ and $g G H 3$ genes is similar to that seen for the ovine $G H 2-N$ and GH2-Z genes (Fig. 1) but it is not yet clear whether the situations in goat and sheep are exactly equivalent.

\section{SEQUENCE STUDIES}

Alignments of the various sheep and goat GH gene sequences discussed below have been prepared and are available on the World Wide Web at the following address: http://www.biols.susx.ac.uk/ Home/Mike_Wallis/GHAlign.

The sequence of cDNA corresponding to sheep pituitary GH was reported by Warwick \& Wallis (1984) and subsequently confirmed (Warwick et al. 1989, Lacroix et al. 1996). The protein sequence predicted from this agrees with the known sequence for sheep GH. Orian et al. (1988) presented a sequence for the sheep $\mathrm{GH}$ gene; the coding sequence predicted from this corresponds to the cDNA sequence for pituitary $\mathrm{GH}$, and this gene presumably codes for the hormone expressed in the pituitary. This was confirmed by Ofir \& Gootwine (1997) who showed that the sequence of the single GH1 gene (Gh1 allele) is identical to the sequence described by Orian et al. (1988) and that the (partial) sequence of the $G H 2-N$ gene is also very similar to this, although there is some variation between strains of sheep. Lacroix et al. (1996) described sequences for three GH-related cDNAs derived from sheep placenta. One of these, coding for a protein identical to pituitary preGH, corresponds to the product of the GH1 or GH2-N gene. The other two are very similar and code for a protein differing from pituitary preGH at three amino acid residues, which appears to correspond to the product of the GH2-Z gene. Byrne et al. (1987) provided a rather different sequence for a GH-like gene in sheep, which differs at about 44 nucleotides from the sequence of Orian et al. (1988); in some respects this resembles the $G H 2-Z$ gene, but the match is far from complete. This may reflect variation between sheep strains of the kind noted by Ofir \& Gootwine (1997). Neither Orian et al. (1988) nor Byrne et al. (1987) reported the presence of two $\mathrm{GH}$ genes in the gene libraries that they screened. However, it is notable that Southern blotting of DNA from several individual animals led Byrne et al. (1987) to detect a GH-linked RFLP very similar to that which led Valinsky et al. (1990) to conclude that duplicated GH genes are present in some sheep.

The situation in goat is less clear. The sequence of goat pituitary GH cDNA was reported by Yamano et al. (1988) and Yato et al. (1988) and the $\mathrm{GH}$ gene sequence was described by Kioka et al. (1989). The coding sequence predicted from the gene sequence corresponds to the goat $\mathrm{GH}$ cDNA sequence and this gene was subsequently shown to be the $g G H 1$ gene. Sequence information for the $g G H 2$ and $g G H 3$ genes (i.e. the duplicate genes in the second allele) is not yet available.

\section{STRUCTURE-FUNCTION ASPECTS}

The sequence of the second $\mathrm{GH}$ expressed in the sheep placenta (probably the product of the $\mathrm{GH} 2-\mathrm{Z}$ gene), codes for a protein that differs from pituitary $\mathrm{GH}$ at three sites, one (Pro $\rightarrow$ Leu at position -7 ) in the signal peptide, and two (Gly $\rightarrow$ Arg at position 9 and Gly $\rightarrow$ Ser at position 63) in mature $\mathrm{GH}$ (Lacroix et al. 1996) (the numbering is based on $\mathrm{N}$-terminal Ala as residue 1). The substitution at residue 9 is in the second receptor-binding site on 


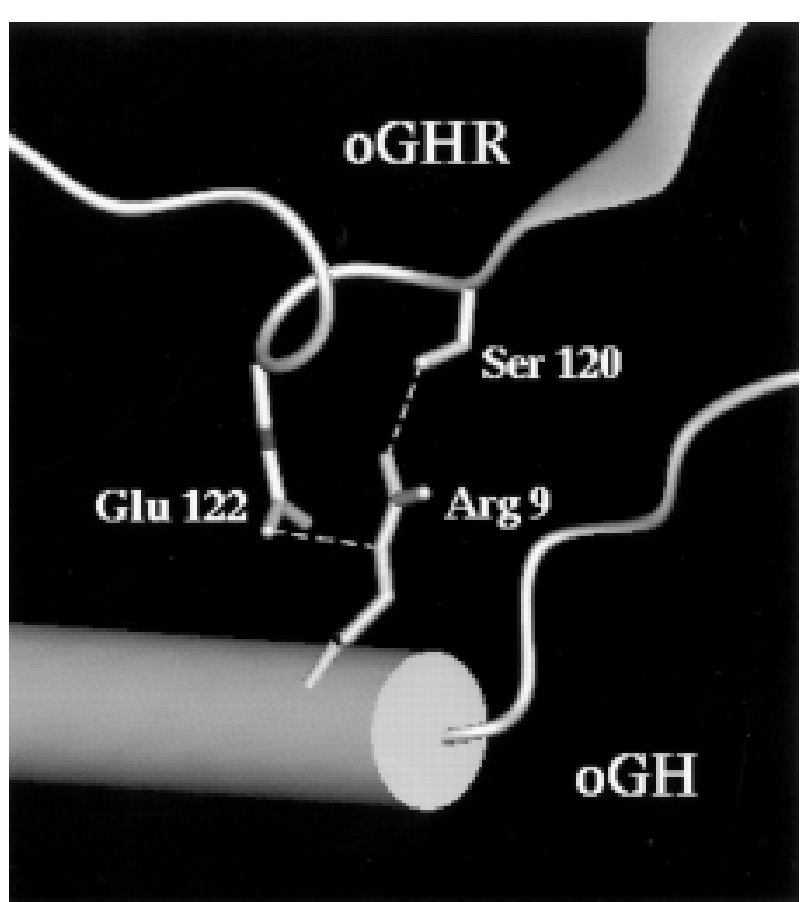

FIGURE 2. Growth hormone-receptor interactions in sheep. A model of part of the site 2 hormone-receptor interface is shown for the complex between the placental ovine $\mathrm{GH}$ (oGH) variant and the $\mathrm{GH}$ receptor (oGHR). The ovine GH-receptor complex $\left(\mathrm{GH}(\mathrm{GHR})_{2}\right)$ was constructed by homology modelling using the QUANTA software package (Molecular Simulations Inc., San Diego, CA, USA) and the CHARMm field for energy minimisation in a Silicon Graphics computer, and starting coordinates based on the human $\mathrm{GH}(\mathrm{GHR})_{2}$ complex (de Vos et al. 1992). Residues Gly ${ }^{9}$ and Gly $^{63}$ were then mutated computatively into Arg and Ser respectively for the placental oGH variant, and the side chains of $\mathrm{Arg}^{9}$ and Ser $^{63}$ and neighbouring residues were allowed to adopt optimal conformations after minimisation. In binding site 2, hydrogen bonds are predicted to form (see dashed lines) between $\mathrm{Arg}^{9}$ (oGH variant) and $\mathrm{Glu}^{122}$ (oGHR) and between $\mathrm{Arg}^{9}$ (oGH variant) and $\mathrm{Ser}^{120}$ (oGHR).

GH as defined by Cunningham et al. (1991) for human GH. Conversion of this residue (Arg) in human GH to Ala led to some lowering of receptor binding (Cunningham et al. 1991), so the Gly $\rightarrow$ Arg conversion in the sheep placental GH may lead to enhanced affinity for the receptor at the second site. This is supported by modelling studies (A Lioupis, unpublished observations) on ovine $\mathrm{GH}-$ introduction of $\mathrm{Arg}$ at position 9 would allow formation of a salt bridge and hydrogen bond to Glu $^{122}$ and Ser $^{120}$ respectively on the receptor, with enhanced binding (Fig. 2).
Residue 63 (Gly $\rightarrow$ Ser substitution in the placental $\mathrm{GH}$ ) is located in binding site 1 in human GH (Cunningham \& Wells 1989, de Vos et al. 1992). The corresponding residue in human GH is Asn, and conversion of this to Ala (Cunningham \& Wells 1989) led to some decrease in receptor binding. The effect of the Gly $\rightarrow$ Ser substitution is difficult to predict, and modelling studies suggest that it would not be great. However, it should be noted that the substitution at residue 63 might introduce a glycosylation site into the protein (a Ser residue in a serine-rich loop); this would accord with the observation of Lacroix et al. (1996) that the second placental GH-like protein that they observed was substantially larger than normal pituitary GH. Introduction of a bulky carbohydrate moiety in the region of binding site 1 might be expected to interfere with receptor binding. Combining this with enhanced binding affinity at binding site 2 might give a GH variant which could form non-productive hormone-receptor complexes - in effect an inhibitor. There is clearly a need for studies on the biological properties of this placental protein.

\section{EVOLUTIONARY SIGNIFICANCE}

How widespread is the GH gene duplication in ruminants? On the whole it seems likely that the duplication occurred during the evolution of the caprine ruminants after divergence of these from other bovid groups. Gene sequences have been reported for GH from ox (Woychik et al. 1982, Gordon et al. 1983) and red deer (Lioupis et al. 1997); in neither case was a second gene isolated, although Southern blotting of restriction digests of bovine genomic DNA did provide some evidence for a second GH-related gene (Woychik et al. 1982, Gordon et al. 1983). It is notable that the sheep GH2-N and GH2-Z genes are very similar - much more similar in non-coding sequence than the sheep GH2-N (or GH1) gene and the bovine GH genesuggesting that the duplication arose rather recently, although gene conversion may have homogenised the two diverging gene sequences as is thought to have happened in the case of human placental lactogens (Chen et al. 1989).

One of the most intriguing aspects of the $\mathrm{GH}$ gene duplication in both goat and sheep is that the duplicate genes exist as an allelic polymorphism with the single (presumably ancestral) form; in neither species has the allele corresponding to the duplication completely replaced that corresponding to the single gene. It seems likely that the two $\mathrm{GH}$ genes arose as the consequence of a single 
gene-duplication event, predating the divergence of sheep and goat. The polymorphism seen in sheep and goat must therefore also have arisen before the divergence of these two species and have been sustained through speciation and during the following 5-7 million years. Such long-lived polymorphism is not completely unprecedented for example it has been shown that polymorphism of MHC proteins extends across mouse and rat species (Figueroa et al. 1988) - but it is certainly unusual. It implies the existence of strong selective forces, presumably involving heterozygote advantage, to maintain it. The nature of such selective forces remains to be elucidated - as yet major physiological differences between sheep of Gh1/Gh1, Gh1/Gh2 and Gh2/Gh2 genotypes have not been detected. Ram lambs with these three genotypes showed no differences with regard to body weight, body composition or most aspects of $\mathrm{GH}$ expression, storage or secretion, although subtle differences were found with respect to pituitary $\mathrm{GH}$ content and responsiveness to GH releasing hormone (Fleming et al. 1997, Gootwine et al. 1997). Detailed physiological studies on goat, pregnant sheep and wild animals remain to be reported. Increased understanding of the basis of this GH polymorphism may have relevance both for our understanding of molecular evolution in general and for animal husbandry/production.

\section{REFERENCES}

Byrne CR, Wilson BW \& Ward KA 1987 The isolation and characterisation of the ovine growth hormone gene. Australian Fournal of Biological Sciences 40 459-468.

Chen EY, Liao Y-C, Smith DH, Barrera-Saldana HA, Gelinas RE \& Seeburg PH 1989 The human growth hormone locus: nucleotide sequence, biology, and evolution. Genomics 4 479-497.

Cunningham BC \& Wells JA 1989 High-resolution epitope mapping of hGH-receptor interactions by alanine-scanning mutagenesis. Science 244 1081-1085.

Cunningham BC, Ultsch M, de Vos AM, Mulkerrin MG, Clauser KR \& Wells JA 1991 Dimerization of the extracellular domain of the human growth hormone receptor by a single hormone molecule. Science 254 821-825.

Figueroa F, Günther E \& Klein J 1988 MHC polymorphism pre-dating speciation. Nature 335 265-267.

Fleming JS, Suttie JM, Montgomery GW, Gunn J, Stuart SK, Littlejohn RP \& Gootwine E 1997 The effects of a duplication in the ovine growth hormone $(\mathrm{GH})$ gene on $\mathrm{GH}$ expression in the pituitaries of ram lambs from lean and fat-selected sheep lines. Domestic Animal Endocrinology 14 $17-24$.

Golos TG, Durning M, Fisher JM \& Fowler PD 1993 Cloning of four growth hormone/chorionic somatomammotropinrelated complementary deoxyribonucleic acids differentially expressed during pregnancy in the rhesus monkey placenta. Endocrinology 133 1744-1752.
Gootwine E, Sise JA, Penty JM \& Montgomery GW 1993 The duplicated gene copy of the ovine growth hormone gene contains a PvuII polymorphism in the second intron. Animal Genetics 24 319-321.

Gootwine E, Ofir R \& Yossefi S 1996 Characterization of PvuII polymorphisms between the ovine growth hormone $\mathrm{GH} 2 \mathrm{-N}$ and GH2-Z gene copies. Animal Biotechnology 7 135-143.

Gootwine E, Suttie JM, McEwan JC, Veenvliet BA, Littlejohn RP, Fennessy PF \& Montgomery GW 1997 The physiological effects of natural variation in growth hormone gene copy number in ram lambs. Domestic Animal Endocrinology 14 381-390.

Gordon DF, Quick DP, Erwin CR, Donelson JE \& Maurer RA 1983 Nucleotide-sequence of the bovine growth hormone chromosomal gene. Molecular and Cellular Endocrinology 33 81-95.

Kioka N, Manabe E, Abe M, Hashi H, Yato M, Okuno M, Yamano Y, Sakai H, Komano T, Utsumi K \& Iritani A 1989 Cloning and sequencing of goat growth hormone gene. Agricultural and Biological Chemistry 53 1583-1587.

Lacroix MC, Devinoy E, Servely JL, Puissant C \& Kann G 1996 Expression of the growth hormone gene in ovine placenta: detection and cellular localization of the protein. Endocrinology 137 4886-4892.

Lioupis A, Wallis OC \& Wallis M 1997 Cloning and characterisation of the gene encoding red deer (Cervus elaphus) growth hormone: implications for the molecular evolution of growth hormone in artiodactyls. Fournal of Molecular Endocrinology 19 259-266.

Ofir R \& Gootwine E 1997 Ovine growth hormone gene duplication-structural and evolutionary implications. Mammalian Genome 8 770-772.

Orian JM, O'Mahoney JV \& Brandon MR 1988 Cloning and sequencing of the ovine growth hormone gene. Nucleic Acids Research 169046.

Schuler LA \& Kessler MA 1992 Bovine placental prolactinrelated hormones. Trends in Endocrinology and Metabolism 3 334-338.

Valinsky A, Shani M \& Gootwine E 1990 Restriction fragment length polymorphism in sheep at the growth hormone locus is the result of variation in gene number. Animal Biotechnology 1 135-144.

de Vos AM, Ultsch M \& Kossiakoff AA 1992 Human growth hormone and extracellular domain of its receptor: crystal structure of the complex. Science 255 306-312.

Wallis M 1992 The expanding growth hormone/prolactin family. Fournal of Molecular Endocrinology 9 185-188.

Wallis M 1994 Variable evolutionary rates in the molecular evolution of mammalian growth hormones. Fournal of Molecular Evolution 38 619-627.

Wallis M 1996 The molecular evolution of vertebrate growth hormones: a pattern of near-stasis interrupted by sustained bursts of rapid change. Fournal of Molecular Evolution 43 93-100.

Warwick JM \& Wallis M 1984 Characterization of mRNA sequences encoding sheep somatotropin (growth hormone) by cloning of pituitary complementary DNA. Biochemical Society Transactions 12 247-248.

Warwick JM, Wallis OC \& Wallis M 1989 Cloning, sequence and expression in Escherichia coli of cDNA for ovine pregrowth hormone. Biochimica et Biophysica Acta 1008 247-250.

Woychik RP, Camper SA, Lyons RH, Horowitz S, Goodwin EC \& Rottman FM 1982 Cloning and nucleotide sequencing of the bovine growth hormone gene. Nucleic Acids Research $107197-7210$.

Yamano Y, Oyabayashi K, Okuno M, Yato M, Kioka N, Manabe E, Hashi H, Sakai H, Komano T, Utsumi K \& 
Iritani A 1988 Cloning and sequencing of cDNA that encodes goat growth hormone. FEBS Letters 228 301-304.

Yamano Y, Abe M, Mikawa S, Kioka N, Manabe E, Sakai H, Komano T, Utsumi K \& Iritani A 1991 Structural analysis of repetitive DNA sequences in the goat growth hormone gene region. Agricultural and Biological Chemistry $\mathbf{5 5}$ 633-639.
Yato M, Yamano Y, Oyabayashi K, Okuno M, Kioka N, Manabe E, Hashi H, Sakai H, Komano T, Utsumi K \& Iritani A 1988 Nucleotide sequence of the growth hormone gene cDNA from goat Capra hircus L. (Tokara). Nucleic Acids Research 163578.

RECEIVED 12 February 1998 